\title{
REKONSTRUKSI AL-ISLAM-KEMUHAMMADIYAHAN (AIK) PERGURUAN TINGGI MUHAMMADIYAH SEBAGAI PRAKSIS PENDIDIKAN NILAI
}

\author{
RECONSTRUCTION OF AL-ISLAM- \\ KEMUHAMMADIYAHAN (AIK) IN MUHAMMADIYAH \\ UNIVERSITIES AS THE PRAXIS OF VALUE EDUCATION
}

\author{
Syamsul Arifin \\ Universitas Muhammadiyah Malang \\ Jl. Bandung No. 1 Malang Jawa Timur 65113 \\ Email: syamsarifin@yahoo.com
}

\begin{abstract}
One of the peculiarities marker at the higher education of Muhammadiyah is providing the education of al Islam and Kemuhammadiyahan (AIK). In the curriculum of the higher education of Muhammadiyah there is a provision that AIK is a compulsory subject, a kind of Islamic religious education must be given in public higher education. However, AIK has a weight of credits and hours of study which is greater than the Islamic religious education at public higher education, which weighs 2 credits and given only one time in one semester, while AIK has a weight of 4-8 credits are given for four semesters. Taking into account the position of the AIK, this paper want elaborate AIK as the praxis of value education. This paper is based on a descriptive study of a number of documents relating to AIK generated by Muhammadiyah and University of Muhammadiyah Malang, one of higher education of Muhammadiyah that serve as an example the case of the development of AIK. At the end of this paper, the authors recommend about the importance of value ducation as a paradigm in developing AIK.
\end{abstract}

Keywords: Al Islam and Kemuhammadiyahan, educational value, Muhammadiyah

\section{Abstrak}

Salah satu penanda kekhasan di Perguruan Tinggi Muhammadiyah adalah penyelenggaraan pendidikan al Islam dan Kemuhammadiyahan (AIK). Pada kurikulum Perguruan Tinggi Muhammadiyah terdapat ketentuan bahwa AlK merupakan materi wajib, semacam pendidikan agama Islam yang wajib diberikan di pendidikan tinggi umum. Namun demikian, AIK memiliki bobot kredit dan jam studi yang lebih besar dari pada pendidikan agama Islam di perguruan tinggi umum, yang berbobot 2 sks dan diberikan hanya satu kali dalam satu semester, sementara AIK memiliki bobot 4-8 sks yang diberikan selama empat semester. Dengan mempertimbangkan posisi AIK tersebut, tulisan ini hendak mengelaborasi AlK sebagai praksis pendidikan nilai. Tulisan ini didasarkan pada riset deskriptif terhadap sejumlah dokumen yang berkaitan dengan AIK yang dihasilkan oleh Muhammadiyah dan Universitas Muhammadiyah Malang, salah satu Perguruan Tinggi Muhammadiyah yang dijadikan sebagai contoh kasus pengembangan AIK. Pada bagian akhir tulisan ini, penulis merekomendasikan tentang pentingnya pendidikan nilai sebagai paradigma dalam mengembangkan AIK.

Kata Kunci: Al Islam dan Kemuhammadiyahan, pendidikan nilai, Muhammadiyah. 


\section{PENDAHULUAN}

Salah satu organisasi sosial Islam yang terpenting di Indonesia sebelum Perang Dunia II dan mungkin juga sampai saat ini, tegas Deliar Noer, ${ }^{1}$ adalah Muhammadiyah. Deliar Noer tidak berlebihan dengan pernyataan tersebut karena sejak kelahirannya pada 18 November 1912 hingga dalam usia yang melampaui satu abad ini, Muhammadiyah bukan sekedar "ada”, tetapi terus memperlihatkan perkembangan yang dinamis. Sebagai fenomena organisme, organisasi jelas Rheinald Kasali, pertamatama dilahirkan, tumbuh, melewati masa kanak-kanak, remaja dan menjadi tua. Organisasi juga menjadi sakit, lumpuh, tidak berdaya, dan akhirnya mati. ${ }^{2}$ Selain Muhammadiyah, ada beberapa organisasi Islam yang lahir pada permulaan abad ke-20, tetapi sebagaimana dikemukakan Rheinald Kasali, organisasi-organisasi terbut bahkan akhirnya mati. Sementara Muhammadiyah dalam menghadapi berbagai tantangan, di samping memiliki daya tahan yang kuat, Muhammadiyah, mengutip kembali Rheinald Kasali, ${ }^{3}$ memiliki kemampuan menciptakan perubahan (change) terutama dari dalam-dengan catatan tidak mengubah jati dirinya-- sehingga tetap memiliki kekuatan dialektis dengan perubahan dari luar yang tidak pernah mengenal kata henti.

${ }^{1}$ Dealiar Noer. 1990. Gerakan Modern Islam di Indonesia: 1900-1942. Jakarta: LP3ES, h. 84

${ }^{2}$ Rheinald Kasali. 2007. Re-Code Your Change DNA: Membebaskan Belenggu-belenggu untuk Meraih Keberanian dan Keberhasilan dalam Pembaharuan. Jakarta: Gramedia, h. 12.

${ }^{3}$ Rheinald Kasali. 2006. Change: Tak Peduli Berapa Jauh Jalan Salah yang Anda Jalani: Putar Arah Sekarang Juga. Jakarta: Gramedia
Daya tahan dan kemampuan Muhammadiyah mengembangkan diri di antaranya terlihat pada kemampuan Muhammadiyah dalam memosisikan dirinya apa yang disebut oleh Mitsuo Nakamura sebagai organisasi "masyarakat sipil Islam" terbesar kedua di Indonesia (the second largest Islamic society organization) in Indonesia). ${ }^{4}$ Konsep yang digunakan Mitsuo Nakamura, Muhammadiyahsebagaisalahsatueksemplar "masyarakat sipil Islam" atau Islamic society organization, sebenarnya merupakan afirmasi terhadap hasil kajian peneliti lainnya-meskipun tidak menggunakan konsep seperti yang digunakan Mitsuo Nakamaura-pada dasarnya ingin mendeskripsikan bahwa sejak kelahirannya karakter Muhammadiyah bukan gerakan politik dalam arti formal. Kajian yang dilakukan Alfian, misalnya, mendeskripsikan $\mathrm{Mu}-$ hammadiyah ke dalam tiga kategori gerakan yang saling berkelindan, yaitu: (1) sebagai gerakan pembaruan keagamaan (as a religious reformist); (2) sebagai agen perubahan sosial (as an agent of social change); dan (3) sebagai kekuatan politik ( as a political change). ${ }^{5}$ Dengan karakter gerakan seperti ini, meskipun bukan sebagai institusi politik dalam arti sempit dan formal, Muhammadiyah yang sejak pada awal-awal kelahirannya beriringan dengan berkecembahnya gerakan nasionalisme, memainkan peran penting mengembangkan kesadaran politik melalui lembaga

${ }^{4}$ Mitsuo Nakamura. 2012. The Crescent Arises over the Banyan Tree: A Study of the Muhammadiyah Movement in a Central Javanase Town, c. 1910s-2010. Singapore: ISEAS, h. XXV

5 Alfian. 1989. Muhammadiyah: The Political Behavior of a Muslim Modernist Organization Under Dutch Colonialism. Yogyakarta: Gadjah Mada University Press, h. 5. 
pendidikan yang dimilikinya. Peran $\mathrm{Mu}-$ hammadiyah dalam konteks masa itu digambarkan oleh George McTurnan Kahin, ${ }^{6}$ tak ubahnya seperti anak sungai yang tenang tetapi dalam dan turut berkontribusi dalam arus nasionalisme politik dan secara diam-diam tetapi berkelanjutan berhasil menghidupkan dan memperkuat arus tersebut.

Salah satu basis institusional terpenting gerakan Muhammadiyah adalah pendidikan. Dibandingkan dengan institusi lainnya yang berkembang menjadi amal usaha Muhammadiyah seperti kesehatan dan ekonomi, jumlah lembaga pendidikan jauh lebih banyak sehingga Muhmmadiyah hampir identik dengan pendidikan. ${ }^{7}$ Seiring dengan usia Muhammadiyah yang telah memasuki satu abad, perkembangan pendidikan yang dimiliki oleh Muhammadiyah juga memperlihatkan kemajuan secara signifikan terutama secara kuantitatif. ${ }^{8}$ Karena begitu pentingnya basis institusional bidang pendidikan dalam gerak langkah Muhammadiyah, pada setiap forum pertemuan yang diselenggarakan

${ }^{6}$ George McTurnan Kahin. 2003. Nasionalisme \& Revolusi Indonesia. Jakarta: Komunitas Bambu, h. 121.

${ }^{7}$ Chairil Anwar, "Sambutan Ketua Majelis Dikti Litbang PP Muhammadiyah" dalam Suyatno et al (ed.).2010. Revitalisasi Pendidikan Muhammadiyah di Tengah Persaingan Nasional dan Global. Jakarta: Uhamka Press,h. xi. Menurut catatan Wikipedia, Muhammadiyah memiliki lembaga pendidikan sebanyak 10314 yang tersebar pada semua jenjang pendidikan (TK-PT) dengan perincian sebagai berikut: TK/TPQ (4623); SD/MI (2604); SMP/MTs (1772); SMA/SMK/MA (1143); PT (172).

${ }^{8}$ Menurut catatan Wikipedia, Muhammadiyah memiliki lembaga pendidikan sebanyak 10314 yang tersebar pada semua jenjang pendidikan (TK-PT) dengan perincian sebagai berikut: TK/TPQ (4623); SD/MI (2604); SMP/MTs (1772); SMA/SMK/MA (1143); PT (172).
Muhammadiyah, pendidikan selalu mendapatkan perhatian penting. Pada muktamar ke-46 yang diselenggarakan pada 3-8 Juli 2010 M (20-25 Rajab 1431H) di Yogyakarta, Muhammadiyah menelorkan pemikiran di bidang pendidikan yang bertajuk, "Revitalisasi Pendidikan Muhammadiyah". Keputusan ini menarik dijadikan bahan kajian karena revitalisasi pendidikan Muhammadiyahseharusnyajugamenyentuh pada salah satu tugas inti pendidikan, yaitu memperkuat dan mengembangkan kualitas peserta di bidang nilai.

Tulisan ini pada gilirannya akan mengkaji Pendidikan al Islam-Kemuhammadiyahan atau yang disebut dengan AIK sebagai praksis pendidikan nilai di Perguruan Tinggi Muhammadiyah (PTM). AIK merupakan salah satu ciri khas PTM sebagaimana ketentuan Pedoman Pimpinan Pusat Muhammadiyah Nomor 02/PEDI/ I.0/B/2012 tentang Perguruan Tinggi Muhammadiyah.PadaPasal9ayat(2)terdapat ketentuan sebagai berikut: "Perguruan Tinggi Muhammadiyah wajib memiliki ciri khas kurikulum Al-Islam Kemuhammadiyahan yang diatur lebih lanjut dengan ketentuan Majelis Pendidikan Tinggi."Sebagai kelanjutan dari ketentuan ini, semua PTM yang tersebar di Indonesia menyelenggarakan pendidikan AIK sejak semester pertama. AIK bisa dikatakan sejenis pendidikan agama Islam (PAI) di perguruan tinggi umum yang wajib diikuti oleh mahasiswa yang beragama Islam. Perbedaannya, kalau PAI cukup diberikan hanya satu semester, sedangkan AIK bisa sampai empat semester. Sekedar contoh, Universitas Muhammadiyah Malang merancang AIK sampai empat semester dengan penjenjangan sebagai berikut: AIK I, AIK II, AIK III, dan AIK IV. 
Pada bagian akhir tulisan ini, penulis akan merekomendasikan beberapa upaya dalam rangka mengembangkan AIK sebagai praksis pendidikan nilai. Tulisan ini didasarkan pada telaah terhadap beberapa dokumen yang bersumber dari Pimpinan Pusat Muhammadiyah yang diakses secara daring (online) dan dokumen-dokumen yang terkait dengan AIK di Universitas Muhammadiyah Malang (UMM). UMM sengaja dipilih karena didasarkan setidaknya pada tiga pertimbangan. Pertama, UMM telah melakukan beberapa rekonstruksi terhadap AIK kurang lebih sejak 1991. Kedua, rekonstruksi yang dilakukan oleh UMM dijadikan salah satu pertimbangan oleh Majelis Pendidikan Tinggi Pimpinan Pusat Muhammadiyah dalam mengeluarkan kebijakan terkait dengan pengembangan AIK pada level nasional. Ketiga, model AIK di UMM dijadikan acuan oleh beberapa PTM terutama yang berada di wilayah Indonesia bagian timur dan PTM yang sedang berkembang.

\section{PEMBAHASAN}

\section{Filsafat Pendidikan Muhammadiyah}

Dengan jumlah lembaga pendidikan yang demikian banyak tersebut, $\mathrm{Mu}$ hammadiyah terbukti bisa melakukan peran strategis yang dapat dirasakan manfaatnya oleh banyak kalangan. Pertama, pendidikan yang dikembangkan oleh Muhammadiyah telah terbukti menjadi institusi strategis dalam mendiseminasikan paham keislaman yang dikembangkan oleh Muhammadiyah. Perkembangan Muhammadiyah sebagai suatu fenomena "society"-bukan hanya sebagai fenomena organisasi--, setidaknya sebagai state of mind, tidak bisa dilepaskan dari proses transfer dan transformasi paham keislaman yang dilakukan secara sistematis melalui institusi pendidikan yang dimiliki Muhammadiyah. Dalam konteks ini, institusi pendidikan al-Islam dan Kemuhammadiyahan (AIK) yang terdapat pada semua Perguruan Tinggi Muhammadiyah (PTM), ikut berperan dalam memengaruhi dan bahkan mengubah cara berfikir (mode of though) mahasiswa terhadap Islam.

Kedua, pendidikan yang dimiliki oleh Muhammadiyah turut memberikan kontribusi terhadap apa yang dalam sosiologi disebut dengan mobilitas sosial. Jika sedikit melakukan tilikan sejarah, misi pendidikan yang dikembangkan oleh Muhammadiyah di antaranya ingin mendorong umat Islam terbebas dari jeratan sebagai kelas jelata yang diakibatkan dari praktik politik etis pemerintah kolonial Belanda9. Berkat pendidikan Muhammadiyah, banyak dari umat Islam yang mengalami mobilitas sosial sebagai kelas menengah. ${ }^{10}$

Kendati memiliki lembaga pendidikan dalamjumlahyangbanyak serta memberikan kontribusi setidaknya terhadap kehidupan umat Islam, pendidikan Muhammadiyah tidak pernah henti-hentinya mendapatkan sorotan dan kritik baik dari kalangan internal Muhammadiyah sendiri maupun dari kalangan luar. Sorotan dan kritik terhadap pendidikan Muhammadiyah di antaranya ada yang bermuatan filosofis.

${ }^{9}$ Lihat, Robert van Niel. 2009. Munculnya Elite Modern Indonesia. Jakarta: Pustaka Jaya Indonesia.

${ }^{10}$ Lihat, Matuki HS. 2010. Kebangkitan Kelas Menengah Santri: Dari Tradisionalisme, Liberalisme, Postradisionalisme hingga Fundamentalisme. Tangerang: Pustaka Dunia. 
Sedangkan lainnya menyoroti pada aspek tata kelola (governance). Sorotan dan kritik terhadap aspek kefilsafatan pendidikan Muhammadiyah pernah diungkap oleh Mohamad Ali dan Marpuji Ali lewat artikelnya yang bertajuk, Filsafat Pendidikan Muhammadiyah: Tinjauan Historis dan Praksis ${ }^{11}$ . Kedua penulis yang juga dosen al-IslamKemuhammadiyahan (AIK) di Universitas Muhammadiyah Surakarta (UMS) itu, menyoal kekosongan pemikiran filsafat yang menyangga bangunan pendidikan Muhammadiyah sejak dari TK sampai PT. Kita kutip pendapat mereka:

Dalam usia Muhammadiyah menjelang satu abad dengan jumlah lembaga pendidikan mulai dari Taman Kanak-kanak sampai dengan Perguruan tinggi, adalah suatu yang aneh Muhammadiyah belum mempunyai filsafat pendidikan. Bagaimana mungkin kerja hiruk-pikuk pendidikan tanpa satu panduan cita-cita yang jelas? Apatah lagi bila dikaitkan dengan upaya mendidik dalam rangka pembentukan generasi ke depan. ${ }^{12}$

Bisa jadi artikel tersebut ditulis sebelum perhelatan Muktamar ke-46 Muhammadiyah yang diselenggarakan di Yogyakarta. Sebab pada muktamar tersebut, Muhammadiyah telah menelorkan suatu keputusan mendasar yaitu, Revitalisasi Pendidikan Muhammadiyah ${ }^{13}$. Dalam keputusan tersebut, yakni pada Bab II,

\footnotetext{
11617/1051

${ }^{12}$ Ibid.

${ }^{13}$ Lihat, Tanfidz Keputusan Muktamar Satu Abad Muhammadiyah dalam http://www.muhammadiyah. or.id/muhfile / d ownload/T anfidz\% 20 Muhammadiyah/Tanfidz\%20Muhammadiyah\%20 Sept\%202010.PDF
}

11 https://publikasiilmiah.ums.ac.id/handle/ terdapat penjelasan tentang Rumusan Filsafat Pendidikan Muhammadiyah. Berikut dikemukakan beberapa poin penting yang terkandung dalam keputusan tersebut:

Pertama, hakikat pendidikan dalam pandangan Muhammadiyah.

Pendidikan Muhammadiyah adalah penyiapan lingkungan yang memungkinkan seseorang tumbuh sebagai manusia yang menyadari kehadiran Allah swt sebagai Robb dan menguasai ilmu pengetahuan, teknologi dan seni (IPTEKS). Dengan kesadaran spiritual makrifat (iman/ tauhid) dan penguasan IPTEKS, seseorang mampu memenuhi kebutuhan hidupnya secara mandiri, peduli sesama manusia yang menderita akibat kebodohan dan kemiskinan, senantiasa menyebarluaskan kemakmuran, mencegah kemungkaran bagi pemuliaan kemanusiaan dalam rangka kehidupan bersama yang ramah lingkungan dalam sebuah bangsa dan tata pergaulan dunia yang adil, beradab dan sejahtera sebagai ibadah kepada Allah.

Pendidikan Muhammadiyah merupakan pendidikan Islam modern yang mengintegrasikan agama dengan kehidupan dan antara iman dan kemajuan yang holistik. Dari rahim pendidikan Islam yang untuk itu lahir generasi muslim terpelajar yang kuat iman dan kepribadiannya, sekaligus mampu menghadapi dan menjawab tantangan zaman. Inilah pendidikan Islam yang berkemajuan.

Kedua, visi dan misi pendidikan $\mathrm{Mu}-$ hammadiyah. Visi (vision) bisa dikatakan sebagai magic formula yang mengandung pernyataan tentang cita-cita atau impian sebuah institusi di masa yang akan datang. Visi pendidikan Muhammadiyah dinyatakan 
sebagai berikut: "Terbentuknya manusia pembelajar yang bertaqwa, berakhlak mulia, berkemajuan dan unggul dalam IPTEKS sebagai perwujudan tajdid dakwah amar ma'ruf nahi munkar." Sedangkan misi (mission) merupakan pernyataan tentang tugas luhur atau suci yang harus dilakukan oleh suatu institusi untuk mencapai visi. Misi pendidikan Muhammadiyah dirumuskan sebagai berikut:

(1) Mendidik manusia memiliki kesadaran ketuhanan (spiritual makrifat).

(2) Membentuk manusia berkemajuan yang memiliki etos tajdid, berfikir cerdas, alternatif dan berwawasan luas.

(3) Mengembangkan potensi manusia berjiwa mandiri, beretos kerja keras, wirausaha, kompetetif dan jujur.

(4) Membina peserta didik agar menjadi manusia yang memiliki kecakapan hidup dan ketrampilan sosial, teknologi, informasi dan komunikasi.

(5) Membimbing peserta didik agar menjadi manusia yang memiliki jiwa, kemampuan menciptakan dan mengapresiasi karya seni-budaya.

(6) Membentuk kader persyarikatan, ummat dan bangsa yang ikhlas, peka, peduli dan bertanggungjawab terhadap kemanusiaan dan lingkungan.

Ketiga, nilai-nilai dasar pendidikan Muhammadiyah (NDPM). Pada keputusan muktamar ke-46 Muhammadiyah juga terdapat pernyataan tentang NDPM. Pernyataan tentang NDPM keputusan tersebut dikaitkan dengan kemampuan historisitas pendidikan Muhammadiyah dalam menghadapi berbagai perubahan zaman yang didasarkan atas nilai-nilai sebagai berikut:
(1) Pendidikan Muhammadiyah diselenggarakan merujuk pada nilai-nilai yang bersumber pada al-Qur'an dan Sunnah Nabi

(2) Rukhul ikhlas untuk mencari ridha Allah SWT menjadi dasar dan inspirasi dalam ikhtiar mendirikan dan menjalankan amal usaha di bidang pendidikan.

(3) Menerapkan prinsip kerja sama (musyarakah) dengan tetap memelihara sikap kritis, baik pada masa Hindia Belanda, Dai Nippon (Jepang), Orde Lama, Orde Baru hingga pasca Orde Baru.

(4) Selalu memelihara dan menghiduphidupkan prinsip pembaruan (tajdid), inovasi dalam menjalankan amal usaha di bidang pendidikan.

(5) Memiliki kultur untuk memihak kepada kaum yang mengalami kesengsaraan (dhuafa dan mustadh'afin) dengan melakukan proses-proses kreatif sesuai dengan tantangan dan perkembangan yang terjadi pada masyarakat Indonesia.

(6) Memperhatikan dan menjalankan prinsip keseimbangan (tawasuth atau moderat) dalam mengelola lembaga pendidikan antara akal sehat dan kesucian hati.

Keempat, unsur-unsur pendidikan. Pendidikan sering dipahami sebagai suatu sistem karena adanya pertautan yang utuh antarberbagai unsur. Dalam dokumen keputusan muktamar ke-46, terdapat paparan tentang aspek-aspek pendidikan Muhammadiyah yang meliputi: (1) Pembelajar; (2) Pembelajaran; (3) Pendidik; (4) Persyarikatan; (5) Manajerial; (6) Kurikulum; (7) Kemasyarakatan.

Rumusan filsafat pendidikan Muhammadiyah yang tertuang dalam keputusan 
muktamarke-46Muhammadiyahsebenarnya masih memerlukan eksplorasi dan elobarasi lebih mendalam. Rumusan tersebut baru bisa dikatakan sebagai "Pengantar Filsafat Pendidikan Muhammadiyah". Sambil menunggu kajian berikutnya terutama dari para pakar pendidikan di kalangan Muhammadiyah, rumusan tersebut telah memiliki kaitan dengan isu-isu utama yang dibahas dalam kajian filsafat pendidikan yang meliputi aspek ontologi, epistemologi, dan epistemologi. Aspek ontologi pendidikan membicarakan tentang hakikat keberadaan pendidikan yang selalu mengait dengan eksistensi kehidupan manusia. Aspek epistemologi pendidikan membahas tentang pengetahuan yang akan disajikan dalam pendidikan untuk mengembangkan potensi manusia sebagai subyek pendidikan. Sedangkan aspekaksiologi dalam pendidikan berkaitan dengan nilai-nilai keutamaan yang dapat mengembangkan pribadi yang bermoral.

Dari sisi ontologis, dalam rumusan filsafat pendidikan Muhammadiyah terdapat pernyataan tentang eksistensi manusia yang memiliki kesadaran spiritual tentang Allah sebagai Realitas Absolut yang selalu hadir dalam kehidupan manusia (omnipresence). Rumusan filsafat pendidikan Muhammadiyah juga mengandung penjelasan tentang aspek epistemologi seperti tampak pada pernyataan:"... pendidikan Islam modern yang menintegrasikan agama dengan kehidupan dan antara iman dan kemajuan yang holistik." Dengan pernyataan ini dapat diartikan bahwa epistemologi keilmuan yang dijadikan dasar untuk mengembangkan potensi manusia adalah (epistemologi) yang berkarakter integralistik, holistik, tidak mengandung pertentangan atau dikotomi antara agama dan ilmu pengetahuan. Sedangkan dari sisi aksiologis, pendidikan Muhammadiyah berkomitmen untuk mengembangkan manusia yang pada dirinya selalu melekat nilai-nilai kebajikan.

Mengapa pendidikan membutuhkan filsafat? Apakah mungkin aktivitas pendidikan dapat mengabaikan filsafat? Dengan mengenyampingkan beragam definisi yang dirumuskan oleh para ahli, dalam tulisan ini filsafat ingin dipahami sebagai sebagai suatu mode of thought (cara atau modus berfikir). Setiap manusia memiliki kemampuan melakukan aktivitas pemikiran. Tetapi tidak semua aktivitas pemikiran bisa dikategorikan sebagai pemikiran filosofis kecuali kalau dicurahkan pada suatu ikhtiar untuk memahami hakikat sesuatu. Inilah yang disebut dengan cara berfikir secara radikal. Dalam Kamus Inggris-Indonesia: An EnglishIndonesian Dictionary, karya John M. Echols dan Hassan Shadily, radikal (radical) di antaranya memiliki pengertian: "sampai ke akar-akarnya." Kata radical sendiri berasal dari bahasa Yunani, radix, yang berarti akar. Jika menggunakan ilustasi sebuah pohon, akar berada pada posisi di dalam tanah. Kekuatan suatu pohon sangat tergantung pada kualitas posisi akar dalam tanah. Semakin dalam posisi akar, maka semakin kuat pula dalam menyangga unsur-unsur pohon yang di atasnya. Dengan menggunakan pohon sebagai ilustrasi, maka yang dimaksud dengan berfikir secara radikal adalah aktivitas memahami sesuatu lebih mendalam dan mendasar, bukan hanya realitas di permukaan yang mudah ditangkap secara inderawi. Maka kalau obyeknya pendidikan, maka yang akan dihasilkan dari berfikir secara radikal adalah suatu pemahaman secara mendalam dan 
mendasar tentang pendidikan. Inilah yang dimaksud dengan esensi (essence), yakni sesuatu yang dipandang paling penting. Dengan demikian, berfikir secara radikal dalam konteks pendidikan berarti suatu ikhtiar untuk memahami esensi (apa yang paling penting) pendidikan. Pemahaman terhadap esensi pendidikan perlu dimiliki oleh semua pemangku kepentingan (stakeholders), lebih-lebih bagi pengelola suatu institusi pendidikan. Menurut Omar Muhammad al-Toumy al-Syaibani: ${ }^{14}$

Falsafah pendidikanitudapat menolong perancang-perancang pendidikan dan orang-orang yang melaksanakannya dalam suatu negara untuk membentuk pemikiran yang sehat terhadap proses pendidikan. Di samping itu dapat menolong terhadap tujuan-tujuan dan fungsi-fungsinya serta meningkatkan mutu penyelesaian masalah pendidikan dan peningkatan tindakan dan keputusan termasuk rancanganrancangan pendidikan mereka, begitu juga untuk memperbaiki peningkatan pelaksanaan pendidikan serta kaedah dan cara mereka mengajar yang mencakup penilaian, bimbingan, dan penyuluhan. Hal itu dapat mewarnai tindakan mereka dengan tujuan tertentu dan memberikan usaha-usaha pendidikan itu suatu merata fikiran dan falsafah. Begitu juga hal itu dapat ia mengaitkan di antara berbagai segi kegiatan dan usaha-usaha yang dilakukannya untuk mencapai tujuantujuan pendidikan. Falsafah pendidikan yang menyeluruh yang dibatasi dalam rangka sejarah bangsa dan kebudayannya dan suasana kerohanian, sosial, ekonomi dan politik dapat menyebabkan pelajarnya, dan orang yang mendalaminya memandang proses pendidikan.

${ }^{14}$ Omar Muhammad al-Toumy al-Syaibani. 1979. Falsafah Pendidikan Islam. Jakarta: Bulan Bintang, h. 1

\section{AlK sebagai Praksis Pendidikan Nilai}

Telah dikemukakan di bagian awal tulisan ini bahwa Muhammadiyah memiliki ribuan institusi pendidikan sejak dari TK sampai PT. Sebagai organisasi berbasis dan berkarakter keagamaan (keislaman), maka wajar jika pendidikan yang dirancang oleh Muhammadiyah selalu diusahakan melekat dengan segala sesuatu yang berhubungan dengan agama (Islam). Salah satu yang menjadi karakter pada pendidikan Muhammadiyah adalah adanya program pendidikan bernama al-Islam-Kemuhammadiyahan (AIK) pada jenjang perguruan tinggi (Perguruan Tinggi Muhammadiyah/ PTM). AIK di PTM bisa disetarakan dengan pendidikan agama pada perguruan tinggi lain di Indonesia yang berkedudukan sebagai mata kuliah wajib kendati hanya berbobot 2 sks. Dalam sistem pendidikan di Indonesia, pendidikan agama menurut Abdul Mu'ti dan Fajar Riza Ul Haq bersifat confessional yang bertujuan menanamkan keyakinan dan membentuk manusia taat kepada agamanya (learning to be religious persons), bukan sekedar sebagai sebagai obyek ilmu pengetahuan (learning to know about religion). ${ }^{15}$ Pemberian status terhadap pendidikan agama sebagai mata kuliah wajib dalam sistem pendidikan nasional juga terkandung maksud sebagai "instrumen" bagi pencapaian tujuan pendidikan nasional. Pada Undang-Undang Republik Indonesia (UU RI) Nomor 20 Tahun 2003, Bab II (Dasar, Fungsi, dan Tujuan), Pasal 3 terdapat pernyataan:

Pendidikan nasional berfungsi mengembangkan kemampuan dan membentuk

${ }^{15}$ Abdul Mu'ti dan Fajar Riza Ul Haq. 2009. Kristen Muhammadiyah: Konvergensi Muslim dan Kristen dalam Pendidikan. Jakarta: al Wasath, h. 12. 
watak serta peradaban bangsa yang bermartabat dalam rangka mencerdaskan kehidupan bangsa, bertujuan untuk berkembangnya potensi peserta didik agar menjadi manusia yang beriman dan bertaqwa kepada Tuhan Yang Maha Esa, berakhlak mulia, sehat, berilmu, cakap, kreatif, mandiri, dan menjadi warga negara yang demokratis serta bertanggung jawab .

Sebagaimana status pendidikan agama dalam sistem pendidikan nasional, AIK dalam sistem pendidikan Muhammadiyah juga memiliki status sebagai mata kuliah wajib yang harus ditempuh oleh semua mahasiswa. Penyelenggaraan AIK di PTM pada umumnya menggunakan model "eksklusif" dan "menghindari" model "inklusif”. Dalam model "eksklusif”, semua mahasiswa tanpa memperhatikan latar belakang agamanya diwajibkan menempuh mata kuliah AIK sebagai pendidikan agama confessional. Model ini berbeda dengan model "inklusif" yang memberi peluang kepada mahasiswa untuk mempelajari beberapa agama. Dalam model ini, menurut Abdul Mu'ti dan Fajar Riza Ul Haq, penyajian agama bersifat non-confessional karena hanya menekankan pada aspek kognitif. Pelaksanaan model ini mengandung maksud untuk meningkatkan pemahaman dan kesadaran terhadap pluralitas agama. Model "inklusif" ini sejalan dengan perkembangan baru dalam studi agama-agama yang mulai menekankan interreligious studies dengan tujuan: "to be religious today is to be interreligious"16. Selain "menghindari" model "inklusif", tidak semua lembaga pendidikan

${ }^{16}$ J.B. Banawirata, "To Be Religious Today is to be Interreligious" dalam Syafa'atun Almirzanah. 2009. When Mystic Masters Meet: Paradigma Baru Relasi Umat Kristiani-Muslim. Jakarta: Gramedia, h. xiii.
Muhammadiyah mengakomodasi ketentuan UU RI Nomor 20 Tahun 2003 Bab V (Peserta Didik), pasal 12 yang mengatakan bahwa setiap peserta didik pada setiap satuan pendidikan berhak: "Mendapatkan pendidikan agama sesuai dengan agama yang dianutnya dan diajarkan oleh pendidik yang segama."

Dengan mengenyampingkan perdebatan tentang model pendidikan agama yang tepat di lembaga pendidikan Muhammadiyah dalam konteks peserta didik yang plural dari sisi agama, yang perlu mendapatkan jawaban secara mendasar adalah bagaimana mengoptimalkan institusi AIK di PTM agar tidak hanya menjadi aksesori formal, tetapi berkontribusi secara signifikan terhadap pengembangan potensi mahasiswa. Optimalisasi potensi AIK ke arah terebut terkendala oleh sejumlah kelemahan yang sekaligus sebagai sasaran kritik banyak kalangan terhadap pelaksanaan AIK di PTM.. Setidaknya ada tiga hal pada AIK yang menjadi sasaran kritik.

Pertama,kualifikasiakademikpengampu AIK. Dari sisi ini, masih ada beberapa pengampu AIK yang belum memenuhi standar minimal berdasarkan ketentuan Bab V Pasal 46 Undang-Undang Republik Indonesia (UU RI) Nomor 14 Tahun 2005 tentang Guru dan Dosen yang menyatakan: "Dosen memiliki kualifikasi akademik minimum: a. lulusan program magister untuk program diploma atau program sarjana; dan b. lulusan program doktor untuk program pascasarjana."

Kedua, kompetensi pengampu AIK. Definisi kompetensi menurut UU RI Nomor 14 Tahun 2005 adalah: "Seperangkat pengetahuan, keterampilan, dan perilaku yang harus dimiliki, dihayati, dan dikuasai oleh guru atau dosen dalam melaksanakan 
tugas keprofesionalan." Kompetensi ini telah menjadi pengatahuan populer bagi semua kalangan yang terlibat secara langsung dalam kegiatan pendidikan. Kompetensi yang harus dimiliki oleh dosen meliputi: kompetensi pedagogik, kompetensi kepribadian, kompetensi profesional, dan kompetensi sosial. Deskripsi masing-masing kompetensi sebagai berikut:

Tabel 1. Deskripsi Kompetensi Pedagogik, Profesional, Kepribadian, dan Sosial

\begin{tabular}{|l|l|}
\hline $\begin{array}{l}\text { Kompetensi } \\
\text { Pedagogik }\end{array}$ & $\begin{array}{l}\text { Kompetensi pedagogik adalah kemampuan } \\
\text { mengelola pembelajaran yang meliputi } \\
\text { pemahaman terhadap karakteristik mahasiswa, } \\
\text { perencanaan, pelaksanaan dan evaluasi } \\
\text { pembelajaran serta pengembangan mahasiswa } \\
\text { untuk mengaplikasikan berbagai potensi yang } \\
\text { dimilikinya. }\end{array}$ \\
\hline $\begin{array}{l}\text { Kompetensi } \\
\text { Profesional }\end{array}$ & $\begin{array}{l}\text { Kemampuan penguasaan materi pembelajaran } \\
\text { secara luas dan mendalam yang memungkinkan } \\
\text { membimbing mahasiswa memenuhi standar } \\
\text { kompetensi. }\end{array}$ \\
\hline $\begin{array}{l}\text { Kompetensi } \\
\text { Kepribadian }\end{array}$ & $\begin{array}{l}\text { Kompetensi kepribadian adalah sifat mantap, stabil, } \\
\text { dewasa, bijak, berwibawa, sehingga kondisi pribadi } \\
\text { guru dapat menjadi contoh bagi mahasiswa. }\end{array}$ \\
\hline Kompetensi & $\begin{array}{l}\text { Kompetensi sosial adalah kemampuan } \\
\text { berkomunikasi secara efektif dengan mahasiswa, } \\
\text { teman sejawat, dan masyarakat. dirinya serta } \\
\text { meningkatkan kualitas pendidikan secara } \\
\text { berkelanjutan mengikut perkembangan zaman. }\end{array}$ \\
\hline
\end{tabular}

Dari keempat kompetensi tersebut, yang paling banyak mendapatkan kritik adalah kompetensi pedagogik pengampu AIK terutama kemampuan dalam menyampaikan materi dengan menggunakan metode yang menarik dan efektif atau yang disebut dengan active learning (pembelajaran aktif). Dalam Peraturan Pemerintah (PP) Nomor 19 Tahun 2005 tentang Standar Nasional Pendidikan (SNP) terdapat pernyataan yang menekankan pada penggunaan pembelajaran aktif: "Proses pembelajaran pada satuan pendidikan diselenggarakan secara interaktif, inspiratif, menyenangkan, menantang,memotivasi peserta didik untuk berpartisipasi aktif, serta memberikan ruang yang cukup bagi prakarsa, kreativitas, dan kemandirian sesuai dengan bakat, minat, dan perkembangan fisik serta psikologis peserta didik." Sementara itu, penyampaian materi AIK masih didominasi oleh metode ceramah yang lebih mengandalkan komunikasi verbal pihak pengampu, sedangkan di sisi lain, mahasiswa cenderung pasif. Metode ceramah memang memiliki kelebihan terutama jika ingin menyampaikan materi yang tidak tersedia dalam bentuk tulisan serta pada saat memberikan pengarahan sebelum melaksanakan tugas. Tetapi yang perlu diperhatikan kekurangan metode ini jauh lebih banyak seperti dikemukakan Hisyam Zaini: ${ }^{17}$

Namun, sayangnya, metode ceramah memiliki beberapa kelemahan, beberapa di antaranya adalah sebagai berikut: (1) Daya tahan mahasiswa untuk berkonsentrasi dan mengandalkan alat indera telinga sangat terbatas. Penelitian yang dilakukan Hartley dan Davies (1978) menunjukkan bahwa perhatian meningkat dari mulai perkuliahan sampai pada sepuluh menit pertama dan menurun setelah itu. Pada sepuluh menit pertama mahasiswa mampu menyerap 70\% informasi yang disampaikan. Sementara itu, pada sepuluh menit terakhir informasi yang dapat diserap oleh mahasiswa hanya $20 \%$; (2) Ketika mendengarkan, mahasiswa sangat mudah terganggu karena mahasiswa lebih terfokus pada apa yang terlihat (visual) daripada yang terdengar (audio); (3) Mahasiswa tidak dapat membandingkan,

${ }^{17}$ Hisyam Zaini, dkk., 2002. Desain Pembelajaran di Perguruan Tinggi. Yogyakarta: CTSD IAIN Sunan kalijaga Yogyakarta, h. 132. 
menganalisis atau mengevaluasi gagasan atau informasi yang disampaikan dosen.

Ketiga, isi, kandungan, atau content AIK. Sorotan terhadap AIK yang menyangkut isi (content) berkaitan dengan lingkup materi, yang dinilai masih terlalu menekankan pada aspek kognitif (pengetahuan teoritik) daripada pengembangan sikap moral keagamaan. Pada bagian pembahasan filsafat pendidikan Muhammadiyah terdapat pertanyaan tentang esensi pendidikan. Pertanyaan ini juga bisa ditujukan kepada AIK; apakah sebenarnya yang menjadi esensi AIK?

Sebagaimana ditulis pada judul tulisan ini, AIK ingin dipahami dalam konteks praksis pendidikan nilai. Pada judul sengaja disisipkan kata praksis (praxis) dengan maksud ingin mendorong terjadinya perubahan cara berfikir (mode of thought) bahwa AIK bukan hanya aktivitas verbal (ceramah/pidato/retorika) menjelaskan segala sesuatu yang berhubungan dengan agama Islam dan Muhammadiyah. Lebih dari sekedar aktivitas verbal-sejalan dengan pengertian kata praksis yakni berbuat atau bertindak-AIK perlu dipahami sebagai tindakan "edukatif" dan sekaligus tindakan "didaktis" yang dapat mendorong peserta didik mewujudkan perilaku bermoral.

Tahapan dari tindakan edukatif-didaktis sampai pada terwujudnya suatu perilaku yang bermoral, tidak bisa dicapai hanya dengan aktivitas pengajaran, tetapi harus melalui pendidikan. Pengajaran, menurut Doni Koesoema $\mathrm{A}^{18}$, lebih berkaitan dengan konteks pedagogis-didaktis dalam relasi

${ }^{18}$ Doni Koesoema A. 2007. Pendidikan Karakter: Strategi Mendidik Anak di Zaman Global.Jakarta: Grasindo, h. 58. antara guru atau dosen dengan murid atau mahasiswa di dalam kelas dalam kerangka tujuan pembelajaran. Sedangkan menurut Azyumardi Azra, ${ }^{19}$ pengajaran lebih menekankan pada proses transfer ilmu belaka, bukan transformasi nilai dan pembentukan kepribadian dengan segala aspek yang dicakupinya. Oleh karena itu,menurut J.I.G.M. Drost. ${ }^{20}$ perlu dibedakan antara proses mengajar dengan belajar (pengajaran) dengan pendidikan yang memiliki makna lebih luas.

Jika coba dianalisis secara etimologis, kata pendidikan berasal dari dua kata kerja yang berbeda, yaitu, dari kata educare dan educere. Kedua kata ini berasal dari bahasa Latin yang kemudian diserap ke dalam bahasa Inggris menjadi education. Educare mengandung pengertian melatih atau menjinakkan (seperti melatih hewan liar menjadi jinak) dan menyuburkan (seperti mengolah tanah pertanian dengan baik sehingga mendatangkan hasil panen yang melimpah). Berdasarkan pada arti harfiah educare ini, Doni Koesoema A kemudian menjelaskan makna pendidikan sebagai berikut: ${ }^{21}$

Jadi, pendidikan merupakan sebuah proses yang membantu menumbuhkan, mengembangkan, mendewasakan, membuat yang tidak tertata atau liar menjadi semakin tertata, semacam proses penciptaan sebuah kultur dan tata keteraturan dalam diri maupun dalam diri orang lain. Selain merupakan semacam

${ }^{19}$ Azyumardi Azra. 1999. Pendidikan Islam: Tradisi dan Modernisasi Menuju Milenium Baru.Jakarta: Logos, h. 3.

20 J.I.G.M. Drost. 1998. Sekolah: Mengajar atau Mendidik? . Yogyakarta: Kanisius, h. 32.

${ }^{21}$ Doni Koesoema A., Pendidikan Karakter...,h. 53 
proses domestifikasi, pendidikan juga berarti proses pengembangan berbagai macam potensi yang ada dalam diri manusia, seperti kemampuan akademis, ralasional, bakat-bakat, talenta, kemampuan fisik, atau daya-daya seni.

Lalu bagaimana makna pendidikan sebagai educere. Menurut analisis Doni Koesoema A, kata educere merupakan gabungan dari preposisi ex (keluar dari) dan kata kerja ducere (memimpin). Jadi, educere berarti suatu kegiatan untuk menarik keluar atau membawa keluar. Berdasarkan pada analisis terhadap pengertian educere ini, maka pendidikan merupakan aktivitas relasional antara pihak yang memimpin dengan pihak yang dipimpin. Sebagaimana pengertian preposisi ex (keluar dari), maka tugas asasi yang harus dijalankan oleh pihak yang memimpin adalah membangkitkan kemampuan pihak yang dipimpin mengatasi (keluar dari) keterbatasan fisik kodrati yang dimilikinya. Kemampuan inilah yang disebut oleh Doni Koesoema A dengan kamampuan keluar secara internal. Selain membangkitkan kemampuan keluar secara internal, pihak yang memimpin, lanjut Doni Koesoema A, juga harus mampu membangkitkan pihak yang dipimpin memiliki kemampuan keluar secara eksternal. Menurut Doni Koesoema A:22

Keluar secara eksternal lebih mengacu pada proses horizontal relasional antara individu dengan individu lain di dalam masyarakat dan lingkungan yang melingkupinya. Manusia, melalui proses pendidikan mampu bekerja sama dengan orang lain di luar dirinya untuk mencapai tujuan bersama dalam sebuah masyarakat

${ }^{22}$ Ibid. yang membantu setiap individu bertumbuh dalam proses penyempurnaan dirinya. Ia mampu bekerja sama dan membaktikan diri pada sebuah kehidupan yang kepentingannya menjangkau kepentingan banyak orang.

Analisis etimologis tersebut kian menyadarkan bahwa pendidikan memiliki makna yang lebih luas dan mendalam daripada pengajaran yang lebih mengutamakan transfer ilmu. Dalam khazanah kepustakaan Islam dikenal istilah "tarbiyah", "ta'lim" dan "ta'dib" yang apabila dipahami secara bersama-sama dapat menjelaskan totalitas makna pendidikan. Sebagai bagian dari aktivitas pendidikan, AIK juga harus dipahami dalam pengertian seperti itu. AIK, dengan demikian, pertama, bukan sekedar aktivitas pengajaran yang lebih menekankan pada proses transfer dan penguasaan teori keagamaan. Kedua, AIK sebagai bagian dari aktivitas pendidikan di PTM perlu dituntut melakukan fungsi pengembangan terhadap potensi yang dimiliki oleh mahasiswa terutama potensi moral. Ketiga, untuk mengembangkan potensi moral tersebut, para pengampu AIK (dosen), sebagai seorang pemimpin, harus mampu mengembangkan aktivitas relasional atau hubungan interpersonal dengan pihak yang dipimpimnya (mahasiswa).

\section{Pengalaman Universitas Muhammadiyah Malang}

Pemikiran ke arah pengembangan AIK sebagai praksis nilai mendesak ditindaklanjuti oleh para pemangku kepentingan (stakeholders) utamanya bagi pihak yang memiliki otoritas secara kelembagaan baik di level nasional (top down) yaitu 
Majelis Pendidikan Tinggi Pimpinan Pusat Muhammadiyah maupun di level masingmasing PTM (bottom up). Kajian yang dilakukan oleh penulis, baik sebagai "orang dalam" (insider) karena telah cukup lama mengajar di UMM, maupun sebagai peneliti, menemukan beberapa dokumen yang menunjukkan bahwa rekonstruksi terhadap AIK telah dilakukan oleh masing-masing PTM seperti yang dilakukan oleh UMM. Sejak 1991 UMM telah melakukan beberapa langkah rekonstruktif terhadap AIK sebagai bagian dari pengembangan UMM secara keseluruhan semenjak di bawah kendali kepemimpinan A. Malik Fadjar pada 1984.

Salah satu kata kunci yang sering dikemukakan oleh A. Malik Fadjar adalah pembaruan (reform). Kata kunci ini sering diulang-ulang oleh A. Malik Fadjar karena dalam pandangannya mengelola pendidikan bukan sekedar aktivitas mempertahankan apa yang sudah ada, suatu aktivitas yang paling mudah untuk dilakukan. Tetapi aktivitas yang cenderung status quo ini, kata A. Malik Fadjar akan segera mendatangkan petaka bagi masa depan sebuah lembaga pendidikan tinggi. Secara perlahan-lahan tetapi pasti, pendidikan tinggi akan tertinggal dalam buritan sejarah akibat ketidakmampuannya mengadakan hubungan yang dialektis dengan realitas yang selalu menuntut sikap transformatif. ${ }^{23}$ Agar UMM tidak berkembang seperti yang dikhawatirkannya itu, A. Malik Fadjar melakukan beberapa pembaruan terhadap pendidikan di UMM. Salah satu yang menjadi sasaran pembaruan A. Malik Fadjar adalah

${ }^{23}$ A. Malik Fadjar. 1998. Visi Pembaruan Pendidikan Islam. Jakarta: Lembaga Pengembangan Pendidikan dan Penyusunan Naskah Indonesia [LP3NI], h. 91.
AIK. A. Malik Fadjar tidak puas jika AIK hanya sebagai aktivitas formal untuk memenuhi tuntutan regulasi Muhammadiyah yang mewajibkan semua PTM menyelenggarakan AIK. Oleh karena itu, di era A. Malik Fadjar, AIK mengalami pemadatan yang semula diberikan sejak semester I sampai semester VIII, diubah hanya sampai pada semester IV. Langkah ini bisa disebut sebagai proses substansiasi agar materi AIK betul-betul menyentuh kebutuhan paling mendasar pada aspek kognitif, afekstif, dan psikomotorik mahasiswa. A. Malik Fadjar kemudian membentuk semacam lembaga "think tank" yang akan menggodok pemikiran strategis untuk pengembangan AIK yang lebih substantif dan memiliki wibawa. Pada 1989 berdirilah Tim Pembina al Islam dan Kemuhammadiyahan (TPAIM) yang kemudian berubah menjadi Pusat Dokumentasi Kajian al Islam dan Kemuhammadiyahan (PDKIM) dan Lembaga Studi Islam dan Kemuhammadiyahan (LSIK). Pendirian LSIK menurut A. Malik Fadjar memiliki tujuan untuk menciptakan suasana kondusif bagi kehidupan keagamaan di lingkungan kampus. Selain itu juga untuk mengembangkan pemikiran Islam dan Kemuhammadiyahanyang cerdas dan kreatif dalam mengantisipasi dinamika perubahan. ${ }^{24}$ Sejak adanya lembaga ini, menurut Imam Suprayogo, mantan Pembantu Rektor I UMM (1984-1996), bisa diselenggarakan kajian dan diskusi tentang AIK seminggu sekali setiap Jumat malam Sabtu. Berikut penjelasan Imam Suprayogo lebih lanjut: ${ }^{25}$

${ }^{24}$ Anwar Hudiyono dan Anshari Thayib. 2006. Darah Guru Darah Muhammadiyah: Perjalanan Hidup Abdul Malik Fadjar. Jakarta: Kompas, h. 118.

25 Sebagaimana dikemukakan secara tertulis oleh Imam Suprayogo dalam Catatan Akhir Sebuah 
Diskusi al Islam dan Kemuhammadiyahan, berjalan beberapa tahun. Hasilnya cukup baik dan menggembirakan. Lewat forum kajian al Islam dan Kemuhammadiyahan ini paling tidak antara dosen satu dengan lainnya, sekalipun berbeda fakultasnya menjadi gampang saling mengenal. Selain itu, dengan makalah-makalah bahan diskusi ini pernah diedit dan dirupakan buku. Selain itu, dengan pendekatan pemberian peran yang dikembangkan, yaitu setiap dosen secara bergantian diwajibkan berbicara tentang Islam pada forum ini, memaksa mereka membaca literatur tentang Islam. Strategi ini juga sekaligus melatih para dosen tetap yang ada pada umumnya masih muda, tampil di hadapan khalayak sesama dosen yang jumlahnya cukup banyak.

Sebagaimana dikemukakan oleh A. Malik Fadjar dan Imam Suprayogo, lembagalembaga di bidang "ke-AIK-an" yang didirikan oleh UMM sejak bernama TPIM, PDKIM, kemudian LSIK, menyelenggarakan kajian yang melibatkan semua dosen di UMM. Kajian yang diselenggarakan pada setiap Jumat malam tersebut diberi nama Studi Islam Interdisipliner (SII). Studi ini dimaksudkan untuk mengembangkan pemahaman terhadap Islam secara komprehensif dengan menggunakan berbagai disiplin keilmuan. Pendekatan ini didasarkan pada suatu pandangan dasar bahwa Islam memiliki misi yang universal yaknirahmatanlil'alamin. Dalam pandangan beberapa tim PDKIM, universalisme Islam tercermin pada: (1) nilai-nilai universal menyangkut berbagai aspek kehidupan; (2) petunjuk tentang bagaimana mewujudkan rahmatan lil 'alamin; (3) jawaban

Pengabdian di Universitas Muhammadiyah Malang, h. 18. memuaskan terhadap pertanyaan di sekitar aspek teleologis kehidupan manusia. ${ }^{26}$ Islam, kata beberapa tim PDKIM, sebenarnya telah memberikan ontologi, epistemologi dan aksiologi kehidupan ini. ${ }^{27}$

Penerjemahan pendekatan dalam SII sebagaimana dikemukakan oleh Imam Suprayogo, dosen diminta menulis makalah yang mengulas tema tertentu dalam Islam berdasarkan perspektif keilmuan yang dikuasainya. Atau sebaliknya, tema tertentu dalam kajian keilmuan dikaitkan dengan Islam. Hasil kajian SII telah menghasilkan publikasi di antaranya buku berjudul Islam Kajian Interdisipliner.Dengan menggunakan pendekatan interdisipliner, UMM rupanya juga ingin memberikan kontribusi terhadap pengembangan pendidikan agama Islam yang pada tahun 1990-an digalakkan apa yang disebut dengan Islam untuk Disiplin Ilmu (IDI).

A. Malik Fadjar tampaknya memberikan respons positif terhadap IDI seperti dapat dibaca pada salah satu tulisannya tentang Islam sebagai Disiplin Ilmu dalam Pendidikan Agama. Bagi A. Malik Fadjar, IDI merupakan terobosan terhadap kelemahan terhadap pendidikan agama Islam yang, di samping terlalu menekankan pada aspek teologis dan ritual, juga kurang dikaitkan dengan disiplin keilmuan umum seperti ekonomi, politik, filsafat, antropologi, dan lain sebagainya. Padahal, jelasnya lebih lanjut, pendidikan agama Islam akan mengundang daya tarik jika menyertakan disiplin ilmu lain dalam menjelaskan ajaran dan fenomena

26 Suyoto, Tobroni, dan Nurhakim. "Misi Rahmatan Lil-“Alamin" dalam PDKIM-UMM (ed.). 1992. Islam Kajian Interdisipliner. Malang: UMM Press, h. 3-4.

${ }^{27}$ Ibid., h. 4 
keagamaan.${ }^{28}$ Respons positif terhadap IDI, di samping diwujudkan dalam kajian reguler SII yang melibatkan para dosen UMM dari berbagai latar belakang keilmuan, juga terlihat pada kurikulum AIK yang disajikan bagi mahasiswa UMM. Pelembagaan pendekatan interdisipliner atau IDI melalui AIK terjadi pada 1996. Pada tahun-tahun sebelumnya, IDI belum terlembagakan dalam AIK. Hal ini bisa dicermati pada dua jilid buku teks al Islam yang terbit pada 1989 (al Islam I) dan 1991 (al Islam II) yang merupakan buku pegangan baik dosen dan mahasiswa. Kedua buku tersebut dicetak dalam jumlah sebanyak mahasiswa baru UMM. Pada kedua buku tersebut, tidak ada pembahasan secara eksplisit tentang IDI. Buku pertama terdiri dari tiga bab dengan pembahasan sebagai berikut: (1) pada bab pertama membahas tentang manusia dan agama dengan penekanan pada fitrah manusia adan agama manusia; (2) pada bab kedua membahas sumber dan ruang lingkup ajaran Islam; (3) pada bab ketiga dibahas tentang dasar-dasar Islam; dan (4) pada bab keempat dibahas al Islam sebagai paradigma. ${ }^{29}$ Adapun buku kedua, memuat tiga bab. Pada bab pertama membahas tentang misi Islam. Bab kedua membahas aktualisasi nilai Islam dalam realitas kehidupan. Sedangkan bab ketiga membahas metodologi pemahaman Islam. Sebagaimana buku pertama, buku kedua juga tidak membahas Islam dalam perspektif IDI. Selain kedua buku tersebut, pada 1990 diterbitkan buku berjudul, Muhammadiyah: Sejarah, Pemikiran dan

28 Lihat, A. Malik Fadjar. 1999. Reorientasi Pendidikan Islam. Cipayung: Fajar Dunia, h. 53.

${ }^{29}$ Abdul Madjid, dkk., 1991. Seri Studi Islam: al Islam I. Malang: Pusat Dokumentasi dan Publikasi Universitas Muhammadiyah Malang.
Amal Usaha. Buku ini bisa disebut sebagai buku suplemen atau penunjang AIK di bidang Kemuhammadiyahan karena merupakan kumpulan tulisan yang diolah dari artikel tentang Muhammadiyah yang dipublikasikan oleh Suara Muhammadiyah. Pelembagaan IDI dalam AIK baru dilakukan pada 1996. Pada tahun ini dilakukan rekonstruksi ${ }^{30}$ materi perkuliahan al Islam dan Kemuhammadiyahan. Dalam rekonstruksi ini, penyelenggaraan AIK diatur dengan penjenjangan dan materi sebagaimana disajikan pada tabel di bawah.

Tabel 2. Pokok-pokok Materi al Islam dan Kemuhammadiyahan ${ }^{3}$

\begin{tabular}{|l|l|l|}
\hline Al Islam I & $\begin{array}{l}\text { Dasar-dasar Islam yang meliputi: tauhid; } \\
\text { manusia dan agama; pengertian, ruang } \\
\text { lingkup dan misi Islam; konsep alam } \\
\text { dalam Islam; dan nasbah antara tauhid } \\
\text { dengan ibadah, akhlak, dan muamalah. }\end{array}$ & Semester I \\
\hline $\begin{array}{l}\text { Kemuham- } \\
\text { madiyahan I }\end{array}$ & $\begin{array}{l}\text { Islam sejarah yang meliputi: periodesasi } \\
\text { sejarah Islam; makna pembaruan, } \\
\text { pembabaruan dalam dunia Islam; } \\
\text { Muhammadiyah sebagai gerakan Islam, } \\
\text { dakwah, pembaharuan; beberapa aspek } \\
\text { tentang Muhammadiyah; dan dinamika } \\
\text { Muhammadiyah dalam pergumulan } \\
\text { keagamaan, sosial, politik, ekonomi, dan } \\
\text { lain sebagainya. }\end{array}$ & Semester II \\
\hline Al Islam II & $\begin{array}{l}\text { Islam ditinjau dari berbagai disiplin } \\
\text { keilmuan (menyesuaikan dengan jumlah } \\
\text { fakultas di UMM). }\end{array}$ & Semester III \\
\hline Kemuham- \\
madiyahan II & $\begin{array}{l}\text { Kapita selekta tentang Muhammadiyah } \\
\text { dan isu-isu aktual yang terkait dengan } \\
\text { Muhammadiyah. }\end{array}$ & Semester IV \\
\hline
\end{tabular}

Pada tahun-tahun berikutnya kegiatan perkuliahan AIK di UMM mengacu pada hasil rekonstruksi yang dilakukan pada 1996. Dari sisi rentang waktu, pemberlakuan rekonstruksi tersebut terbilang lama karena

${ }^{30}$ Istilah rekonstruksi berasal dari tim penyusun silabus al Islam dan Kemuhammadiyahan yang dipimpin oleh Suyoto. Lihat, Silabus Mata Kuliah al Islam dan Kemuhammadiyahan Universitas Muhammadiyah Malang (1996).

${ }^{31}$ Diolah dari, Silabus Mata Kuliah al Islam dan Kemuhammadiyahan Universitas Muhammadiyah Malang (1996). 
baru pada 2010, artinya setelah melewati waktu selama 14 tahun, terjadi perubahan signifikan terhadap AIK. Pada tahun 2010 UMM merumuskan apa yang disebut dengan Kurikulum AIK 2010. Penyusunan Kurikulum AIK 2010 dilatarbelakangi oleh adanya tiga tuntutan. Pertama, amanat dari Qaidah Perguruan Tinggi Muhammadiyah agar PTM memberikan materi tambahan untuk memperkuat ciri khas PTM. Materi tambahan terdiri dari AIK, bahasa Arab, dan Kajian Tafsir al Qur'an dan as Sunnah. Kedua, obsesi UMM untuk menjadi universitas besar dan mendunia yang dapat melahirkan para lulusan yang cerdas dan profesional, yang beriman dan bertaqwa terhadap Tuhan yang Maha Esa, berakhlak mulia dan mampu bersaing di dunia kerja. Obsesi ini, menurut tim penyusun Kurikulum AIK 2010, memerlukan persiapan mental dan kepribadian yang tangguh serta harus disiapkan dengan baik secara sistematik dalam proses penyelenggaraan pendidikannya. Kemudian sebagai latar belakang yang ketiga, perkembangan global yang menurut tim penyusun Kurikulum AIK 2010, telah memberi warna-warna budaya yang cenderung merendahkan martabat manusia dan nilai-nilai akhlak yang mulia. Kurikulum AIK 2010 dengan demikian diharapkan mengambil bagian dalam mewarnai penetrasi budaya dan nilainilai positif dalam menghadapi perubahan tersebut. ${ }^{32}$

Dibandingkan dengan rekonstruksi AIK pada 1996, Kurikulum AIK 2010 memuat perubahan sebagai berikut: per- tama, penyebutan atau nomenklatur perkuliahan AIK tidak lagi dipisah seperti pada rekonstruksi AIK 1996, tetapi disebut secara integratif, yaitu AIK. Jika pada rekonstruksi AIK pada 1996 disebut: al Islam I, Kemuhammadiyahan I, al Islam II, dan Kemuhammadiyahan II, maka dalam Kurikulum AIK 2014 penyebutannya menjadi: AIK I, AIK II, AIK III, dan AIK IV.

Kedua, Kurikulum AIK 2010 memuat tujuan AIK secara umum, sedangkan rekonstruksi AIK 1996, hanya memuat tujuan pada masing-masing jenjang AIK, yakni tujuan al Islam I dan II serta tujuan Kemuhammadiyaha I dan II. Tujuan AIK secara umum menurut Kurikulum AIK 2010 dirumuskan sebagai berikut:

(1) memberikan pemahaman tentang ajaran Islam yang dapat menumbuhkembangkan kekuatan iman dan amal shaleh; (2) memberikan keterampilan membaca dan memahami al Qur'an dan al Hadist sebagai sumber utama ajaran Islam; (3) memberikan keterampilan beribadah yang berdasar pada al Qur'an dan al Hadist; (4) memberikan pemahaman tentang Muhammadiyah sebagai gerakan Islam, dakwah, dan tajdid (pembaharuan); (5) memberikan guidline untuk berperilaku positif (berakhlak karimah) dalam kehidupan yang berdasar pada nilai-nilai keislaman dan kemuhammadiyahan. ${ }^{33}$

Ketiga, pada Kurikulum AIK 2014 terdapat rumusan Standar Kompetensi (SK), sementara pada rekonstruksi AIK 1996 belum ada. Rumusan SK pada Kurikulum AIK 2010 sebagai berikut:

${ }^{32}$ Abdul Haris, dkk, 2010. Kurikulum Pendidikan al Islam dan Kemuhammadiyahan. Malang, UMM Press, h. 1.

${ }^{33}$ Ibid., h. 2. 
(1) mampu membaca dan memahami al Qur'an dengan baik dan benar; (2) memiliki pengetahuan dan pemahaman aqidah dan ibadah yang sesuai dengan tuntutan al Qur'an dan Hadist yang shahih; (3) menghayati pengetahuan tentang aqidah dan ibadah serta terampil mengaktualisasikan dalam aktivitas seharihari sehingga terpancar dalam sifat dan perilaku; (4) memahami Muhammadiyah secara utuh mulai dari asal-usul ideologi, paham keagamaan, strategi, gerakan, makna kehadiran, hingga nilai-nilai yang dijunjung tinggi dan menjadi perhatian Muhammadiyah; (5) memiliki pengetahuan tentang al Qur'an dan as Sunnah kaitannya dengan akhlak dalam kehidupan sosial; (6) dapat menghayati pengetahuan akhlak dalam kehidupan sosial dan terampil mengaktualisasikan dalam kerja keilmuan maupun kerja kemanusiaan. ${ }^{34}$

Keempat, perubahan signifikan pada Kurikulum AIK 2013 jika dibandingkan dengan rekonstruksi AIK pada 1996 adalah adanya penjenjangan peserta perkuliahan AIK berdasarkan kemampuan mahasiswa dalam membaca al Qur'an dan pengetahuan dasar keislaman. Untuk mengetahui kemampuan mahasiswa pada dua bidang tersebut dan penempatannya dalam jenjang tertentu (marhalah), Kantor AIK sebagai Unit Pelaksana Teknis (UPT) AIK menyelenggarakan tes penempatan dan pengelompokan (placement test). Perubahan signifikan lainnya, pada Kurikulum AIK 2010 terdapat program sertfikasi khusus AIK I yang disatukan dengan pelaksanaan P2KK (Program Pembentukan Kepribadian dan Kepemimpinan) yang wajib diiikuti oleh semua mahasiswa baru. Dengan demikian, AIK I tidak diselenggarakan secara reguler

${ }^{34}$ Ibid. sebagaimana AIK II, III, dan IV, tetapi diberikan secara integratif dengan P2KK.

Mahasiswa baru diwajibkan mengikuti program ini yang diatur secara gelombang atau per angkatan. Masing-masing angkatan terdiri dari 250 mahasiswa yang berasal dari berbagai macam program studi. Dari segi waktu, P2KK dirancang selama satu minggu (Senin-Sabtu) yang dipusatkan di Rusunawa Universitas Muhammadiyah Malang. P2KK menyerupai 'pesantren kilat' karena mahasiswa selama mengikuti P2KK harus tinggal di Rusunawa. Selama mengikuti P2KK, mahasiswa mendapatkan materi AIK yang ditekankan pada pemahaman dan praktik ibadah. Selain materi yang berkaitan dengan AIK, mahasiswa peserta P2KK juga mendapatkan materi pengembangan soft skill yang meliputi: kepribadian, kepemimpinan, keterampilan sosial, keterampilan akademik, dan budaya perguruan tinggi ${ }^{35} \mathrm{Hasil}$ yang diperoleh mahasiswa dari P2KK kemudian dikonversi untuk mata kuliah AIK I. Selain P2KK, program sertifikasi berikutnya adalah Pembinaan Baca Tulis al Qur'an yang dikhususkan bagi mahasiswa jenjang atau level dasar (mubtadiah). Pada tabel di bawah ini disajikan program dan materi AIK berdasarkan Kurikulum AIK 2010 (Tabel 3) ${ }^{36}$ dan program sertifikasi (Tabel 4$)^{37}$.

${ }^{35}$ Atok Miftahul Huda, dkk., Membentuk Pribadi \& Pemimpin Unggul: Membangun Peradaban Utama (Materi Penunjang Program Pembentukan Kepribadian dan Kepemimpinan [P2KK]) (Malang: Aditya Media Publishing, tt), h. ix-x.

${ }^{36}$ Abdul Haris, dkk., Kurikulum Pendidikan..., h. 3

${ }^{37} \mathrm{Ibid}$. 
Tabel 3. Materi AIK Berdasarkan Pengelompokan Kemampuan Mahasiswa

\begin{tabular}{|c|c|c|c|}
\hline $\begin{array}{l}\text { Level } \\
\text { (Marhalah) }\end{array}$ & Peserta & Materi & Pelaksanaan \\
\hline \multirow{4}{*}{$\begin{array}{l}\text { Mubtadiah } \\
\text { (Basic/ } \\
\text { Dasar) }\end{array}$} & \multirow{4}{*}{$\begin{array}{l}\text { Mahasiswa } \\
\text { yang belum } \\
\text { bisa membaca } \\
\text { al Qur'an dan } \\
\text { non-Muslim }\end{array}$} & $\begin{array}{l}\text { Teori dan Praktik } \\
\text { Ibadah/P2KK }\end{array}$ & Semester I \\
\hline & & 2. Aqidah dan Ibadah & Semester II \\
\hline & & 3. Kemuhammadiyahan & Semester III \\
\hline & & $\begin{array}{l}\text { 4. Akhlak dan } \\
\text { Muamalah }\end{array}$ & Semester IV \\
\hline \multirow{4}{*}{$\begin{array}{l}\text { Mutawas- } \\
\text { sithah } \\
\text { (Menengah) }\end{array}$} & \multirow{4}{*}{$\begin{array}{l}\text { Mahasiswa } \\
\text { yang sudah } \\
\text { bisa membaca } \\
\text { al Qur'an } \\
\text { dan memiliki } \\
\text { pengetahuan } \\
\text { dasar yang } \\
\text { cukup }\end{array}$} & $\begin{array}{l}\text { Teori dan Praktik } \\
\text { Ibadah/P2KK }\end{array}$ & Semester I \\
\hline & & 2. Aqidah dan Ibadah & Semester II \\
\hline & & 3. Kemuhammadiyahan & Semester III \\
\hline & & $\begin{array}{l}\text { 4. Akhlak dan } \\
\text { Muamalah }\end{array}$ & Semester IV \\
\hline \multirow{4}{*}{$\begin{array}{l}\text { Mutaqad- } \\
\text { dimah } \\
\text { (Tinggi/ } \\
\text { Advance) }\end{array}$} & \multirow{4}{*}{$\begin{array}{l}\text { Mahasiswa } \\
\text { sudah bisa } \\
\text { membaca al } \\
\text { Quran dan } \\
\text { bahasa Arab } \\
\text { dan memiliki } \\
\text { pengetahuan } \\
\text { agama di atas } \\
\text { rata-rata }\end{array}$} & $\begin{array}{l}\text { Teori dan Praktik } \\
\text { Ibadah/P2KK }\end{array}$ & Semester I \\
\hline & & 2. Aqidah dan Ibadah & Semester II \\
\hline & & 3. Kemuhammadiyahan & Semester III \\
\hline & & $\begin{array}{l}\text { 4. Akhlak dan } \\
\text { Muamalah }\end{array}$ & Semester IV \\
\hline
\end{tabular}

Tabel 4. Program Sertifikasi AIK

\begin{tabular}{|l|l|l|l|}
\hline Program & Peserta & Pelaksanaan & Keterangan \\
\hline P2KK & $\begin{array}{l}\text { Seluruh } \\
\text { Mahasiswa } \\
\text { Baru }\end{array}$ & Semester I & $\begin{array}{l}\text { Diselenggarakan secara } \\
\text { intensif selama satu } \\
\text { minggu }\end{array}$ \\
\hline $\begin{array}{l}\text { Pembinaan } \\
\text { Baca Tulis al } \\
\text { Qur'an }\end{array}$ & $\begin{array}{l}\text { Mahasiswa } \\
\text { Kelas } \\
\text { Mubtadiah }\end{array}$ & Semester II & $\begin{array}{l}\text { Dilaksanakan seminggu } \\
\text { sekali selama satu } \\
\text { semester sebagai syarat } \\
\text { mengikuti AlK III }\end{array}$ \\
\hline
\end{tabular}

Kelima, pada Kurikulum AIK 2010 terdapat penekanan kepada dosen AIK untuk menggunakan strategi pembelajaran yang bercorak fisolofis dan sufistik. Dengan kedua pendekatan ini, mahasiswa diharapkan memahami secara mendalam dan utuh tentang agama (pendekatan filosofis), dan mahasiswa merasakan kebahagiaan dalam beragama (pendekatan sufistik).

\section{PENUTUP}

Setelah membaca beberapa dokumen terutama dokumen yang terkait dengan AIK di UMM sebagai contoh kasus, maka bisa disimpulkan bahwa UMM telah melakukan upaya-upaya pengembangan terhadap AIK. Mengingat AIK merupakan ciri khas PTM, maka pengembangan terhadap AIK semestinya juga dilakukan oleh PTM di luar UMM. Pengembangan terhadap AIK yang telah dilakukan oleh UMM dapat direkonstruksi sebagai berikut: pertama, pada paruh pertama dekade 1990-an, UMM memperkuat keberadaan lembaga strategis yang berfungsi sebagai "think tank" untuk mengembangkan AIK secara mendasar dan sistemik. Sebagai "think tank" AIK, lembaga ini telah mampu melakukan kerja-kerja intelektual untuk menemukan apa yang bisa disebut dengan substansi AIK. Pada periode ini, substansi AIK dipahami sebagai pranata pendidikan untuk memahami, menghayati, dan mewujudkan misi Islam sebagai agama rahmatan lil 'alamin. Kemudian pada paruh kedua dekade 1990-an sampai 2010, terjadi pengembahan fase kedua yang disebut sebagai langkah rekonstruktif terhadap materi AIK. Pada fase kedua ini, mulai ada penguatan terhadap materi AIK dari perspektif IDI. Pengembangan berikutnya terjadi pada tahun 2010 yang melahirkan Kurikulum AIK 2010. Melalui Kurikulum AIK 2010 ini terjadi perubahan pada semua aspek AIK seperti tujuan umum AIK, Standar Kompetensi, desain pembelajaran, dan evaluasi.

Meskipun telah diupayakan langkahlangkah pengembangan, setidaknya pada kasus UMM, belum ada upaya pengembangan yang didasari oleh suatu paradigma pendidikan AIK sebagai praksis pendidikan 
nilai.Menuruthematpenulis, pengembangan AIK dengan menggunakan paradigma ini penting diupayakan dengan pertimbangan, AIK sebenarnya bisa disetarakan dengan pendidikan agama Islam, bukan pendidikan keagamaan. Setara dengan pendidikan agama Islam, materi AIK dirancang secara terbatas hanya berupa materi dasar di bidang Islam dan Kemuhammadiyahan. Hal ini berbeda dengan pendidikan keagamaan yang memang dirancang untuk menghasilkan orang-orang yang ahli di bidang ilmu-ilmu keagamaan. Dengan mempertimbangkan "keterbatasan" pada AIK, substansiasi perlu dilakukan kembali yaitu dengan memberikan penekanan pada aspek nilai. Dalam konteks ini, AIK dipahami sebagai suatu nilai, yakni patokan normatif (baik-buruk) yang mengarahkan tindakan seseorang dalam berbuat baik dan menghindari keburukan serta kejahatan. Lalu nilai-nilai apa saja yang hendak dijadikan patokan normatif?

Tahapan diskursif mutlak diperlukan untuk melakukan apa yang disebut oleh seorang filsuf klasik, Plato, pengujian secara kritis terhadap apa yang disebut baik dan buruk. ${ }^{38}$ Para pemangku kepentingan (stakeholders) AIK perlu berdiskusi untuk merumuskan nilai-nilai AIK. Sekedar sebagai perbandingan, mungkin perlu dibaca kembali pemikiran Nurcholish Madjid yang telah merumuskan dua dimensi nilai dalam pendidikan agama. Menurut Nurcholish Madjid, secara substantif materi pendidikan agama berkisar pada dua dimensi: dimensi ketuhanan dengan penekanan pada ketaqwaan dan dimensi kemanusiaan yang ditekankan pada pengembangan rasa

${ }^{38}$ Nimrod Aloni. 2007. Enhancing Humanity The Philosophical Foundations of Humanistic Education. Netherlands: Springer, h. 16 kemanusiaan kepada sesama. Berdasarkan pada pemahaman terhadap dua dimensi tersebut, Nurcholish Madjid kemudiaan mengontruksi nilai-nilai yang dapat memperkuat dimensi pertama yang terdiri dari: iman, Islam, ihsan, taqwa, ikhlas, tawakkal, syukur, dan sabar. Kemudian nilai-nilai yang memperkuat dimensi kedua terdiri dari: silaturrahim (shila al rahim), persaudaraan (ukhuwah), persamaan (al musawah), adil (adl), baik sangka (husn zhan), rendah hati (tawadlu), tepat janji (al wafa'), lapang dada (insyirah), dapat dipercaya (al amanah), perwira (iffah), hemat (qawamiyah), dan dermawan (al munfiqun). ${ }^{39}$

Setelah kontruksi nilai-nilai sebagai buah dari diskursus berhasil dilakukan, pada tahapan selanjutnya perlu dipikirkan pengetahuan-pengetahuan dasar yang dapat memperkuat mahasiswa dalam memahami, menghayati, dan mewujudkan nilai-nilai tersebut dalam kehidupan sehari-hari. Ambillah contoh nilai iman. Kembali mengutip Nurcholish Madjid, iman diartikan sebagai sikap batin yang penuh kepercayaan kepada Tuhan. ${ }^{40}$ Nilai ini tentu mutlak ditanamkan kepada mahasiswa. Pertanyaannya, pengetahuan dasar apa yang perlu dikuasai oleh mahasiswa agar nilai iman tersebut kuat dari sisi kognitif, merasuk dari sisi afektif, dan mampu diwujudkan dalam kehidupan sehari-hari? Pengetahuan dasar yang dapat memperkuat nilai ini di antaranya adalah aqidah Islamiyah. Namun yang perlu diperhatikan, agar tidak mengulangi kesalahan yang sering terjadi pada praktik pendidikan agama Islam

${ }^{39}$ Nurcholish Madjid. 1997. Masyarakat Religius. Jakarta: Paramadina, h. 126-137.

${ }^{40}$ Ibid., h. 130 
yang juga menular pada AIK, yakni adanya kecenderungan verbalistik, maka perlu dipikirkan strategi pembelajarannya. Oleh karena itu, AIK sebagai praksis pendidikan nilai tidak cukup dipahami dalam kerangka pendidikan nilai an sich dimana dosen hanya menjelaskan nilai-nilai tertentu secara verbal. AIK sebagai praksis pendidikan nilai hendaknya dipahamidalam kerangka pendidikan menghidupkan nilai (living values education) yang menekankan pada penciptaan lingkungan berbasis nilai. Oleh karena itu, pengembangan AIK sebagai praksis pendidikan nilai meniscayakan kehadiran suatu sistem dalam mana nilainilai tertentu hidup. Salah satu bagian dari sistem itu adalah dosen. Dosen AIK hendaknya pada dirinya melekat apa yang disebut oleh Abdullah Nashih Ulwan dengan "sifat-sifat asasi pendidik": ikhlas, taqwa, memiliki ilmu pengetahuan, santun/ pemaaf, dan menyadari tanggung jawab. ${ }^{41}$

${ }^{41}$ Abdullah Nashih Ulwan. 2015. Pendidikan Anak dalam Islam. Sukoharjo: Insan Kamil, h. 643-668.

\section{SUMBER BACAAN}

Abdul Haris, dkk. (2010): Kurikulum Pendidikan al Islam dan Kemuhammadiyahan. Malang, UMM Press.

Alfian (1989): Muhammadiyah: The Political Behavior of a Muslim Modernist Organization Under Dutch Colonialism. Yogyakarta, Gadjah Mada University Press

Almirzanah, Syafa'atun (2009): When Mystic Masters Meet: Paradigma Baru Relasi Umat Kristiani-Muslim. Jakarta, Gramedia.

Atok Miftahul Huda, dkk. (tt.): Membentuk Pribadi \& Pemimpin Unggul: Membangun Peradaban Utama (Materi Penunjang Program Pembentukan Kepribadian dan Kepemimpinan [P2KK]). Malang, Aditya Media Publishing.

Azra, Azyumardi (1999): Pendidikan Islam: Tradisi dan Modernisasi Menuju Milenium Baru. Jakarta, Logos.

Drost, J.I.G.M. (1998): Sekolah: Mengajar atau Mendidik? Yogyakarta, Kanisius.

Fadjar, A. Malik (1998): Visi Pembaruan Pendidikan Islam. Jakarta, Lembaga Pengembangan Pendidikan dan Penyusunan Naskah Indonesia.

(tt.): Reorientasi Pendidikan Islam. Cipayung, Fajar Dunia.

Hudiyono, Anwar dan Anshari Thayib (2006): Darah Guru Darah Muhammadiyah: Perjalanan Hidup Abdul Malik Fadjar. Jakarta, Kompas.

Kasali, Rheinald (2007): Re-Code Your Change DNA: Membebaskan Belenggu-belenggu untuk Meraih Keberanian dan Keberhasilan dalam Pembaharuan. Jakarta, Gramedia.

(2006): Change: Tak Peduli Berapa Jauh Jalan Salah yang Anda Jalani, Putar Arah Sekarang Juga. Jakarta, Gramedia. 
Koesoema A., Doni (2007): Pendidikan Karakter: Strategi Mendidik Anak di Zaman Global. Jakarta, Grasindo.

Madjid, Abdul, dkk. (1991): Seri Studi Islam: al Islam I. Malang, Pusat Dokumentasi dan Publikasi Universitas Muhammadiyah Malang .

Matuki HS (2010): Kebangkitan Kelas Menengah Santri: Dari Tradisionalisme, Liberalisme, Postradisionalisme hingga Fundamentalisme. Tangerang, Pustaka Dunia.

McTurnan Kahin, George (2013): Nasionalisme \& Revolusi Indonesia. Jakarta, Komunitas Bambu.

Mu'ti, Abdul dkk. (2009): Kristen Muhammadiyah: Konvergensi Muslim dan Kristen dalam Pendidikan. Jakarta, al Wasath.

Muhammad al-Toumy al-Syaibani, Omar (1979): Falsafah Pendidikan Islam. Jakarta, Bulan Bintang.

Nakamura, Mitsuo (2012): The Crescent Arises over the Banyan Tree: A Study of the Muhammadiyah Movement in a Central Javanase Town, c. 1910s-2010. Singapore, ISEAS.

Nimrod Aloni (2007): Enhancing Humanity The Philosophical Foundations of Humanistic Education. Netherlands, Springer.

Noer, Dealiar (1990): Gerakan Modern Islam di Indonesia 1900-1942. Jakarta, LP3ES.

Nurcholish Madjid (1997), Masyarakat Religius. Jakarta, Paramadina.

Silabus Mata Kuliah al Islam dan Kemuhammadiyahan Universitas Muhammadiyah Malang (1996).

Suprayogo, Imam: Catatan Akhir Sebuah Pengabdian di Universitas Muhammadiyah Malang.

Suyatno et al (ed.) (2010): Revitalisasi Pendidikan Muhammadiyah di Tengah Per- saingan Nasional dan Global. Jakarta, Uhamka Press.

Suyoto, dkk., (1992): "Misi Rahmatan Lil"Alamin” dalam PDKIM-UMM (ed.), Islam Kajian Interdisipliner. Malang, UMM Press.

Tanfidz Keputusan Muktamar Satu Abad Muhammadiyah dalam http:// www.muhammadiyah.or.id/ muhfile/download/Tanfidz\%20 Muhammadiyah / T anfidz $\% 20$ Muhammadiyah\%20Sept\%202010.PDF

Ulwan, Abdullah Nashih (2015): Pendidikan Anak dalam Islam. Sukoharjo, Insan Kamil.

Van Niel, Robert (2009): Munculnya Elite Modern Indonesia. Jakarta, Pustaka Jaya Indonesia.

Zaini, Hisyam dkk. (2002): Desain Pembelajaran di Perguruan Tinggi. Yogyakarta, CTSD IAIN Sunan kalijaga Yogyakarta.

https://publikasiilmiah.ums.ac.id/ handle/11617/1051 